\title{
Impact of Financial Development on Income Inequality in Vietnam
}

\author{
LE QUOC HOI \\ National Economics University - hoilq@neu.edu.vn \\ CHU MINH HOI \\ Vietnam Institute of Economics - hoicm.vie@vass.gov.vn
}

\section{ARTICLE INFO ABSTRACT}

Article history:

Received:

Apr. 152015

Received in revised form:

Aug. 172015

Accepted:

Mar. 252016
Utilizing the approach of constructing indicators treated as representatives for degree of financial development at provincial level of Vietnam over the 2002-2012 period along with Generalized Method of Moments (GMM), this study inspects the nexus between financial development and income inequality. To a certain extent the empirical findings present evidence to show that financial market expansion in Vietnam widens income inequality, through which some policy recommendations are provided with regard to reducing the inequality of income distribution across the society.

Keywords:

Financial development, income inequality,

GMM. 


\section{Problem statement}

Inequality is not advantageously conducive to long-term growth, and in the long run costs of overcoming social consequences are enormous once the increasing problem is perceived among social groups. Riots erupted in Egypt in 2011 were caused by its citizens' being aware of such a huge gap between the rich and the poor that it became intolerable to them. As reported by the World Bank (2014a), 76\% and 53\% of urban and rural population respectively in Vietnam felt deeply concerned about the income inequality. Another noticeable matter from the report is that the concern was voiced more by the youth group, implying that awareness of the prevailing problem would be heightened for at least one more generation. The increasing inequality is one of the factors that influence the probability of escaping the middle-income trap by such a developing country as Vietnam (Ohno, 2010).

Along with the rapid growth in recent years, the rise in inequality in Vietnam was recorded from results of the surveys on living standards and labor and/or employment. The empirical studies of Le (2010) and Nguyen and Pham (2012) stressed that the income gap has been caused by differences in socioeconomic conditions, education, culture, lifestyle, and so forth, which affect the likelihood of having access to resources and living strategies of different income groups, thereby causing income inequality. More importantly, the increasing income inequality in Vietnam has been resulting from existing growth models (Le, 2010; Chu \& Dong, 2015), including such basic macroeconomic variables as trade growth, inflation, and investment, etc.

One factor that plays a vital role in Vietnam's economic growth is the development of financial system. Since early 2000 alone the national economy has witnessed a boom in credit growth and money supply with its peak in 2007 (an increase by approximately 54 percentage points). Asset size of the financial-banking system of Vietnam is currently equivalent to $200 \%$ of GDP of the whole economy (World Bank, 2014b). The importance of the financial system to economic growth has been confirmed in many studies, such as Tran (2008) and Nguyen and Anwar (2009). However, the exponential growth in credit and money supply throughout a long period has led to the instability of the macro economy, most clearly exhibited through inflation volatility.

The growth of the economy has been strongly supported by development of the financial sector, but the upward trend in the gap between income and perceived income inequality can be viewed as a sign of long-term risks posed to macro-economic stability 
and social security. Thus, the conduct of this study is to verify the impact of financial development on income inequality in Vietnam.

\section{Theoretical bases and empirical evidence}

\subsection{Financial development}

Financial development is a concept with broad connotations, expressed in many different dimensions. According to the World Economic Forum (2011), it covers 'the factors, policies, and institutions that lead to effective financial intermediation and markets, as well as deep and broad access to capital and financial services.' Regarding this definition, seven dimensions corresponding to the pillars of financial development are provided, namely: (i) institutional environment; (ii) business environment; (iii) financial stability; (iv) banking financial services; (v) non-banking financial services; (vi) financial markets; and (vii) financial access. To quantify the degree of financial development, the World Bank (2014c) introduced nearly one hundred different indicators, classsified into four categories, including: (i) financial depth; (ii) financial access; (iii) efficiency; and (iv) stabilization.

In fact, the ratios of private credit, total loans, and M2 to GDP are common measures of the financial depth, whereas the proportion of enterprises or small- and medium-sized enterprises with credit limit, or the ratio of market capitalization outside of the top 10 largest companies to total market capitalization is commonly used to approximate access to financial markets. The efficiency itself is often measured by the gap between deposit and lending rates, net interest margin (NIM), and turnover ratio.

\subsection{Income inequality}

Different views are shared, but to understand the term in the most common and simple way, inequality of income denotes unequal income distribution among individuals or social groups. According to OECD (2011), the income inequality reflects how physical resources are distributed in society. Houghton and Kandker (2009) maintained that income inequality is associated with poverty but has broader connotations. In the concept of poverty itself attention is paid to income or expenditure per capita and the distribution of income/expenditure of the lowest income groups, whereas inequality refers more to income distribution across the entire population. 
The Gini coefficient is a common measure of income inequality, valued between 0 and 1 to reflect the status between absolute equality (similar income distribution among all individuals) and absolute inequality (entire income earned by one single individual). According to Cornia and Court (2001), this coefficient ranges within 0.30-0.45, a safe and reasonable range for countries pursuing the goals of high economic growth and stability. In addition, two other inequality measures include: (i) the income gap between the richest and the poorest groups, i.e. the ratio of the total income of the fifth quintile to the total income of the first quintile; and (ii) the ' 40 percent' standard developed by the World Bank, which assesses the $40 \%$ of the population with the lowest income controls (the proportions of less than $12 \%, 12-17 \%$, and greater than $17 \%$ indicate high inequality, middle inequality, and relative equality, respectively).

\subsection{Relation between financial development and income inequality}

The financial development-income inequality nexus really came to notice in the early 90s. The nonlinear model proposed by Greenwood and Jovanovic (1990) addressed this relationship through the fact that the financial system opened up financial investment opportunities. Assuming that each individual in the economy may decide on or invest in low-risk projects with low returns or high-risk projects offering higher returns, the financial system in gradual development would serve to allocate resources to the domains with the highest yields, in addition to establishing a portfolio that can neutralize the risks and maximize the returns, in which investors may participate. However, this requires a certain fee; while some should need time for asset accumulation before accepted as qualified participants, others who possess large enough amounts of assets may possibly join and then be rewarded with high earnings. The income gap, hence, in the early period of the development process is widened. Nevertheless, when the financial market reaches its saturation point, all the participation in the portfolio as was mentioned will be encouraged without constraints imposed by asset ownership, and the inequality will start to decline. These are several basic aspects of the nonlinear theory on the relationship between the financial development and income inequality, or the inverted-U model.

Contrarily, Galor and Zeira (1993) developed a theoretical model to explain the linear relationship between the two factors. Assuming that individuals of the same generation receive an inheritance from the previous one and the assets are valued differently, corresponding to the income earned by each household, the inequality would then be assumed to exist at the beginning of the generation. Individuals may decide to spend their 
life time working in the manufacturing sector with unskilled workers or to invest in human capital development to subsequently work where higher incomes are offered. The investment costs themselves can be financed through borrowings from financial markets, which in turn, however, are imperfect, so the loans may only be received by those who obtain large enough assets (as inheritance). Those who may not, unfortunately, are supposed to work in low-income sectors and so are their offspring. Nevertheless, the situation will change if the markets are in healthy enough development to remove the cost of finance for the poorest; not only will every individual be motivated to invest in his human capital and work for higher income, but inequality will also be reduced.

In addition, Banerjee and Newman's (1993) linear model suggested three career options, corresponding to low-to-high levels of income, including subsistence, working, self-employment, and entrepreneurship. Investment costs spent to pursue the third and fourth occupational choices are covered by inheritance or partly covered through financial markets. However, the wealth level should be large enough to qualify for a loan, or the agents are to decide to work for such a low wage over employment as their future generations. Inequality is accordingly inevitable but may decline as financial markets grow larger to allow for every kind of loan and higher-income career pursuits.

\subsection{Empirical research}

Up to the present quite a few empirical studies have been conducted. At the national level Ang (2010), using data for India between 1951 and 2005 and the Error Correction Model (ECM), indicated that financial development reduces income inequality. By employing data of 21 provinces in rural China over the period of 1991-2000 and using the Generalized Method of Moments (GMM), Liang (2006a) showed that the provinces with more developed financial markets exhibit lower inequality levels, and similar conclusions were also drawn in Liang's (2006b) analyses of data for the urban areas of 29 provinces in the same country. At the transnational level and with a dataset of 22 African nations during 1990-2004, Batuo et al. (2010) detected lower levels of inequality for those with further developed financial systems. Furthermore, Kappel (2010) investigated the case of 78 countries from 1960 to 2006, concluding that the financial development facilitates more equality in income distribution, and similar results were also achieved in another study of Canavire-Bacarreza and Rioja (2008) for the case of Latin American countries. Nevertheless, some research demonstrated that the financial development may or may not lead to increasing inequality. For instance, Law and Tan (2009) confirmed that 
there exists no development-inequality relation in Malaysia, whereas Jauch and Watzka (2012), on examining a dataset of 138 countries across the 1960-2008 period, found a significantly positive relation.

In Vietnam Le and Chu (2013) learnt from the provincial data between 2002 and 2008 and a few indicators relating to financial firms, which proxy for financial development, that a negative nexus exists between the development and income inequality. Still, the financial firms have been performing an unimportant role in Vietnam, causing them to scarcely reflect different dimensions of the financial development. The outcome, thus, cannot be verified without more significant proxies adopted.

\section{Quantitative model, research data, and methodology}

\subsection{Quantitative model}

By approaching the indicators of financial development and other economic variables, the quantitative model of this study can be constructed as follows:

$$
I N E Q_{i, t}=\beta_{0}+\beta_{1} . I N E Q_{i, t-1}+\beta_{2} . F D_{i, t}+\beta_{j} . X_{i, t}+\mu_{i}+\varepsilon_{i, t} \text { with } \mathrm{j}>3
$$

where INEQ denotes the level of inequality, proxied by Gini coefficient, and FD is financial development, proposed by Newmand and O'Tool (2012). Specifically, the two FD indicators are measured by the volume of credit and net income of private and state enterprises as below:

Pcredit $=\left[\sum\right.$ credit of private firms $] /[$ net income of private firms $]$

Pcredit_share $=\left[\sum\right.$ credit of private firms $] /\left[\sum\right.$ credit of private and state firms $]$

Other control variables are also included in the model, namely: (i) real GDP per capita (Rgdppc); (ii) human capital (Humancap), estimated using average years of schooling; (iii) inflation (INF); (iv) domestic trade openness (Dotradeop), measured by total retail sales of goods and services as a share of GDP; (v) government expenditure (Govexp); (vi) state sector investment (Sinvest), as a share of GDP; (vii) private sector investment (Pinvest), as a share of GDP; (viii) foreign direct investment (Finvest), as a share of GDP; (ix) current expenditure (Chitx), as a share of GDP; and (x) development investment expenditure (Chidtpt), as a share of GDP. In the model $\mu$ represents fixed effect (constant over time), and $\varepsilon$ is an unobserved random component. Subscripts (i,t) denote the $i$ th observation at period $t$. 


\subsection{Data}

The research data were collected from GSO. Particularly, calculations of INEQ and Humancap are based on data of the survey on living standards from 2002 to 2012, while the two indicators of FD are measured using business survey data in the same period. The dataset was treated as panel data with $\mathrm{T}=6$ and $\mathrm{N}=60$ (since 2002 there has been separation and mergers of local provinces as between Can Tho and Hau Giang, Dak Lak and Dak Nong, Dien Bien and Lai Chau, and Hanoi and Ha Tay). Since the living standard survey data are supposed to have been collected every two years and the 2014 data have not officially been provided, the dataset of this study is confined to the 2012 observations.

\subsection{Generalized method of moments}

Theoretically and in the reality of data collection, Eq. 1 has potential drawbacks that may cause inefficiency to the estimation or even unreliability if not overcome, including the following:

(i) FD may be endogenous because it can be affected by the factors outside the model, such as the development of information technology that facilitates instant, secure, and convenient processes in banking transactions. The FD may also be predetermined, i.e. it is influenced by shocks of the past; for example, the credit tightening or loosening of the past few years has an impact on the level of market development in the present and future;

(ii) A few factors that are constant over time $\left(\mu_{i}\right)$, such as the geographical location or demographic characteristics of a province/city can be correlated with other explanatory variables in the model; and

(iii) The introduction of $\operatorname{INEQ}_{\mathrm{t}-1}$ to the model may imply autocorrelation. Technically, we cannot yet assert any correlation between INEQ $\mathrm{t}_{-1}$ and $\mathrm{INEQ}_{\mathrm{t}}$; however, the aforementioned theories all hinted that inequality in a certain period could determine that in the coming one.

A panel dataset features a short period of time $(T=6)$, as opposed to a large number of observation $(\mathrm{N}=60)$.

Fixed effect $\left(\mu_{i}\right)$ will be removed by Difference Generalized Method of Moments (DGMM), whereby difference of Eq. 1 is taken to obtain the following equation:

$$
\Delta I N E Q_{i, t}=\beta_{1} . \Delta I N E Q_{i, t-1}+\beta_{2} . \Delta F D_{i, t}+\beta_{j} . \Delta X_{i, t}+\Delta \varepsilon_{i, t}
$$


Nevertheless, it is necessary to find an instrumental variable to control for endogeneity and autocorrelation for the new error term $\left(\Delta \varepsilon_{i, t}\right)$. According to La Porta et al. (1997), some factors affecting (yet not affected by) financial development, such as financial laws or lender's rights, can be viewed as useful instruments. Still, it is difficult to find a powerful one in reality as in this study, and using INEQt-1 with short time panel data and multiple observations, suggested by previous studies, together with the GMM, proves an optimal solution accordingly. Since the similar case has been verified by Soto (2009), regarding the system GMM (Arellano \& Bond, 1991) as more effective than others, it is adopted to the following estimation.

\subsubsection{Autocorrelation testing}

Arellano-Bond test for the residual terms in Eq. 2 is to confirm which lag orders of endogenous variables in the model can be considered suitable instrument variables. For instance, if correlation exists of first difference of $\varepsilon_{i, t}$, then $\mathrm{Gini}_{\mathrm{i}, \mathrm{t}-2}$ will have an endogenous relation to $\varepsilon_{i, t-1}$ since $\varepsilon_{i, t-1}$ is part of $\Delta \varepsilon_{i, t}=\varepsilon_{i, t}-\varepsilon_{i, t-1}$. Thus, Gini $i_{i,-2}$ cannot satisfy the conditions, but higher lag orders are required. In a general sense, to test for the k-order autocorrelation, it is important to consider $\mathrm{AR}(\mathrm{k}+1)$ in Eq. 2.

\subsubsection{Testing for suitability of overidentified model}

During the application of system GMM, a model is said to be underidentified, exactly identified, or over-identified if the number of instrumental variables is less than, equal to, or greater than that of the estimated coefficients. Sargan-Hansen test is aimed at the general suitability of the set of instrumental variables, including lags and those outside the model (if any). However, there has been no specific information on the exact number of the instrumental variables, and introducing too many of these to the model, in performing robust regression to overcome the problem of heteroskedasticity, may result in less reliable test results. Roodman (2009) followed the rule of thumb that the number of intrumental variables should not exceed the observation groups. Due to the null hypothesis of the Sargan-Hansen test that the overidentifying restrictions are valid (which is plausible), the p-value in this test should be as high as possible.

\section{Estimated results and discussion}

The results are presented in Tables 1 and 2 with Pcredit and Pcredit_share acting as proxies for financial development. In Table 1 the estimated coefficients of Pcredit for five out of seven regressions are significantly positive at $5 \%$ or $10 \%$ levels. Together with the 
regression results, those of $\mathrm{AR}(1)$ and $\mathrm{AR}(2)$ tests on autocorrelation in Eq. 1 and Hansen test on the suitablility of overidentified model are also displayed. These testing results are consistent with the expectation, preliminarily hinting that the financial development and income inequality are positively related.

\section{Table 1}

Regression results with Pcredit

Dependent variable: $\log ($ Gini)

\begin{tabular}{|c|c|c|c|c|c|c|c|}
\hline $\begin{array}{c}\text { Explanatory } \\
\text { variable }\end{array}$ & $1 \mathrm{~A}$ & $2 \mathrm{~A}$ & $3 \mathrm{~A}$ & $4 \mathrm{~A}$ & $5 \mathrm{~A}$ & $6 \mathrm{~A}$ & $7 \mathrm{~A}$ \\
\hline L.LnGini & $\begin{array}{c}0.0300 \\
(0.0966)\end{array}$ & $\begin{array}{c}0.0250 \\
(0.0944)\end{array}$ & $\begin{array}{c}0.0373 \\
(0.0956)\end{array}$ & $\begin{array}{c}0.0157 \\
(0.1018)\end{array}$ & $\begin{array}{c}0.0156 \\
(0.1101)\end{array}$ & $\begin{array}{c}0.0277 \\
(0.1027)\end{array}$ & $\begin{array}{c}0.0252 \\
(0.0982)\end{array}$ \\
\hline Pcredit & $\begin{array}{l}0.0071^{* *} \\
(0.0033)\end{array}$ & $\begin{array}{l}0.0061^{*} \\
(0.0033)\end{array}$ & $\begin{array}{l}0.0054^{*} \\
(0.0031)\end{array}$ & $\begin{array}{l}0.0059^{*} \\
(0.0033)\end{array}$ & $\begin{array}{c}0.0056 \\
(0.0035)\end{array}$ & $\begin{array}{c}0.0055 \\
(0.0034)\end{array}$ & $\begin{array}{l}0.0060^{*} \\
(0.0031)\end{array}$ \\
\hline Rgdppc & $\begin{array}{c}0.0010 \\
(0.0007)\end{array}$ & $\begin{array}{l}0.0016^{*} \\
(0.0008)\end{array}$ & $\begin{array}{l}0.0017^{*} \\
(0.0008)\end{array}$ & $\begin{array}{l}0.0017^{*} \\
(0.0009)\end{array}$ & $\begin{array}{c}0.0018^{*} \\
(0.0010)\end{array}$ & $\begin{array}{l}0.0015^{*} \\
(0.0009)\end{array}$ & $\begin{array}{c}0.0014 \\
(0.0010)\end{array}$ \\
\hline Humancap & $\begin{array}{c}- \\
0.0200^{* * *} \\
(0.0100)\end{array}$ & $\begin{array}{l}-0.0170^{*} \\
(0.0100)\end{array}$ & $\begin{array}{l}-0.0125 \\
(0.0101)\end{array}$ & $\begin{array}{l}-0.0170^{*} \\
(0.0090)\end{array}$ & $\begin{array}{l}-0.0130 \\
(0.0108)\end{array}$ & $\begin{array}{l}-0.0168 \\
(0.0112)\end{array}$ & $\begin{array}{l}-0.0165 \\
(0.0104)\end{array}$ \\
\hline Inf & $\begin{array}{l}0.0023^{*} \\
(0.0013)\end{array}$ & $\begin{array}{l}0.0024^{*} \\
(0.0013)\end{array}$ & $\begin{array}{l}0.0025^{* *} \\
(0.0012)\end{array}$ & $\begin{array}{l}0.0024^{*} \\
(0.0013)\end{array}$ & $\begin{array}{l}0.0026^{*} \\
(0.0013)\end{array}$ & $\begin{array}{l}0.0025^{*} \\
(0.0013)\end{array}$ & $\begin{array}{l}0.0024^{*} \\
(0.0013)\end{array}$ \\
\hline Dotradeop & $\begin{array}{c}0.0003 \\
(0.0006)\end{array}$ & $\begin{array}{c}0.0005 \\
(0.0006)\end{array}$ & $\begin{array}{c}0.0005 \\
(0.0006)\end{array}$ & $\begin{array}{c}0.0005 \\
(0.0007)\end{array}$ & $\begin{array}{c}0.0006 \\
(0.0007)\end{array}$ & $\begin{array}{c}0.0004 \\
(0.0007)\end{array}$ & $\begin{array}{c}0.0004 \\
(0.0007)\end{array}$ \\
\hline GovSize & - & $\begin{array}{c}0.0010 \\
(0.0008)\end{array}$ & $\begin{array}{c}0.0010 \\
(0.0008)\end{array}$ & - & - & - & - \\
\hline Chitx & - & - & - & $\begin{array}{c}0.0016 \\
(0.0020)\end{array}$ & $\begin{array}{c}0.0012 \\
(0.0021)\end{array}$ & - & - \\
\hline Chidtpt & - & - & - & $\begin{array}{c}0.0007 \\
(0.0031)\end{array}$ & $\begin{array}{c}0.0010 \\
(0.0031)\end{array}$ & - & - \\
\hline Sinvest & - & - & - & - & - & $\begin{array}{l}-0.0001 \\
(0.0007)\end{array}$ & - \\
\hline
\end{tabular}


Dependent variable: $\log (\mathrm{Gini})$

\begin{tabular}{lccccccc}
\hline $\begin{array}{l}\text { Explanatory } \\
\text { variable }\end{array}$ & $1 \mathrm{~A}$ & $2 \mathrm{~A}$ & $3 \mathrm{~A}$ & $4 \mathrm{~A}$ & $5 \mathrm{~A}$ & $6 \mathrm{~A}$ & $7 \mathrm{~A}$ \\
\hline Pinvest & - & - & - & - & - & 0.0011 & - \\
& & & & & & & \\
& & & & & & & \\
\end{tabular}

Notes: $*$ and $* *$ denote significance levels of $10 \%$ and $5 \%$ respectively; the values in parentheses are standard deviation adjusted for heteroskedasticity; L.Y denotes first lag of Y.

Given Table 2's results, six out of seven regressions indicate that the estimated coefficients of Pcredit_share are statistically positive at 5\% or $10 \%$ levels. The results of various tests on autocorrelation and suitablility of overidentified model are also consistent with the expectation, supporting those from Table 1. Therefore, in the scope of this research there is no contradiction in the empirical results during changes in the proxies for financial development. The results, furthermore, demonstrate both the negative impact of inflation and the positive impact of foreign investment on income distribution, whereas the effects of others are still vague, which requires that further research be conducted into their possible tendencies. 
Also, in this research the introduction of L.Sinvest and L.Pinvest is to check robustness. In theory, richer groups tend to have a large marginal propensity to save, accelerating the process of capital accumulation as a source of investment in the next period and subsequently have effects on economic growth and income distribution.

\section{Table 2}

Regression results with Pcredit_share

\begin{tabular}{|c|c|c|c|c|c|c|c|}
\hline \multicolumn{8}{|c|}{ Dependent variable: $\log ($ Gini) } \\
\hline $\begin{array}{l}\text { Explanatory } \\
\text { variable }\end{array}$ & $1 \mathrm{~B}$ & $2 \mathrm{~B}$ & $3 \mathrm{~B}$ & $4 \mathrm{~B}$ & $5 \mathrm{~B}$ & $6 \mathrm{~B}$ & $7 \mathrm{~B}$ \\
\hline \multirow{2}{*}{ L.LnGini } & 0.0491 & 0.0381 & 0.0400 & 0.0412 & 0.0439 & 0.0613 & 0.0736 \\
\hline & 0.0922 & $(0.0822)$ & $(0.0822)$ & $(0.0873)$ & $(0.0858)$ & $(0.0928)$ & $(0.0945)$ \\
\hline \multirow{2}{*}{ Pcredit_share } & $0.0019^{* *}$ & $0.0017^{*}$ & $0.0016^{*}$ & 0.0016 & $0.0017^{*}$ & $0.0016^{*}$ & $0.0016^{*}$ \\
\hline & $(0.0009)$ & $(0.0009)$ & $(0.0009)$ & $(0.0010)$ & $(0.0009)$ & $(0.0008)$ & $(0.0009)$ \\
\hline \multirow{2}{*}{ Rgdppc } & 0.0012 & $0.0022^{* *}$ & $0.0022^{* *}$ & $0.0020^{* *}$ & $0.0023^{* *}$ & 0.0012 & 0.0013 \\
\hline & $(0.0008)$ & $(0.0010)$ & $(0.0010)$ & $(0.0009)$ & $(0.0010)$ & $(0.0008)$ & $(0.0008)$ \\
\hline \multirow{2}{*}{ Humancap } & -0.0164 & -0.0136 & -0.0116 & -0.0134 & -0.0109 & -0.0108 & -0.0155 \\
\hline & $(0.0101)$ & $(0.0095)$ & $(0.0096)$ & $(0.0100)$ & $(0.0097)$ & $(0.0107)$ & $(0.0107)$ \\
\hline \multirow{2}{*}{ Inf } & 0.0019 & $0.0022^{*}$ & $0.0023^{*}$ & $0.0022^{*}$ & $0.0022^{*}$ & 0.0020 & 0.0021 \\
\hline & $(0.0013)$ & $(0.0013)$ & $(0.0013)$ & $(0.0013)$ & $(0.0012)$ & $(0.0014)$ & $(0.0013)$ \\
\hline \multirow{2}{*}{ Dotradeop } & 0.0003 & 0.0004 & 0.0004 & 0.0004 & 0.0005 & 0.0003 & 0.0002 \\
\hline & $(0.0006)$ & $(0.0006)$ & $(0.0006)$ & $(0.0006)$ & $(0.0006)$ & $(0.0006)$ & $(0.0006)$ \\
\hline GovSize & - & $\begin{array}{c}0.0013 \\
(0.0008)\end{array}$ & $\begin{array}{c}0.0013 \\
(0.0008)\end{array}$ & - & - & - & - \\
\hline Chitx & - & - & - & $\begin{array}{c}0.0019 \\
(0.0018)\end{array}$ & $\begin{array}{c}0.0020 \\
(0.0018)\end{array}$ & - & - \\
\hline Chidtpt & - & - & - & $\begin{array}{c}0.0020 \\
(0.0020)\end{array}$ & $\begin{array}{c}0.0021 \\
(0.0019)\end{array}$ & - & - \\
\hline Sinvest & - & - & - & - & - & $\begin{array}{c}0.0009 \\
(0.0013)\end{array}$ & - \\
\hline Pinvest & - & - & - & - & - & -0.0004 & - \\
\hline
\end{tabular}




\begin{tabular}{|c|c|c|c|c|c|c|c|}
\hline \multicolumn{8}{|c|}{ Dependent variable: $\log ($ Gini $)$} \\
\hline $\begin{array}{l}\text { Explanatory } \\
\text { variable }\end{array}$ & $1 \mathrm{~B}$ & $2 \mathrm{~B}$ & $3 \mathrm{~B}$ & $4 \mathrm{~B}$ & $5 \mathrm{~B}$ & $6 \mathrm{~B}$ & $7 \mathrm{~B}$ \\
\hline & & & & & & $(0.0012)$ & \\
\hline L.Sinvest & - & - & - & - & - & - & $\begin{array}{c}0.0004 \\
(0.0006)\end{array}$ \\
\hline L.Pinvest & - & - & - & - & - & - & $\begin{array}{c}0.0009 \\
(0.0011)\end{array}$ \\
\hline Finvest & - & - & $\begin{array}{l}-0.0011 \\
(0.0007)\end{array}$ & - & $\begin{array}{l}-0.0012^{*} \\
(0.0007)\end{array}$ & $\begin{array}{l}-0.0013^{*} \\
(0.0008)\end{array}$ & $\begin{array}{l}-0.0013^{*} \\
(0.0007)\end{array}$ \\
\hline $\begin{array}{l}\text { Number of } \\
\text { observations }\end{array}$ & 300 & 300 & 300 & 300 & 300 & 300 & 300 \\
\hline $\begin{array}{l}\text { Number of } \\
\text { instruments }\end{array}$ & 32 & 33 & 34 & 36 & 35 & 37 & 37 \\
\hline $\mathrm{AR}(1)$ test & 0.000 & 0.000 & 0.000 & 0.000 & 0.000 & 0.000 & 0.000 \\
\hline $\mathrm{AR}(2)$ test & 0.776 & 0.748 & 0.742 & 0.796 & 0.762 & 0.760 & 0.837 \\
\hline Hansen test & 0.238 & 0.263 & 0.294 & 0.249 & 0.305 & 0.306 & 0.250 \\
\hline
\end{tabular}

Notes: * and ** denote significance levels of $10 \%$ and 5\% respectively; the values in parentheses are standard deviation adjusted for heteroskedasticity; L.Y denotes first lag of Y.

Finally, another test on nonlinear relation is conducted by using sqFD (squared FD) and other similar estimation techniques. Yet, no estimated coeffcients of this variable are statistically significant; we cannot yet conclude the existence of the nonlinear nexus between financial development and income inequality. Thus, in the most general sense and as given by the estimated results, the higher the financial development revealed by a province/city, the greater the income gap it may account for.

Accordingly, contrary to predictions from the theoretical models as proposed by Galor and Zeira (1993) and Banerjee and Newman (1993), financial development in Vietnam does not result in greater equality in income distribution. This also contrasts with the findings from other empirical studies conducted in China, India, Pakistan, and some African countries. However, if we assume that the provinces/cities in VN are in the early stage of economic development, then the results reflect the likelihood that the 
development-inequality nexus in the case of Vietnam fundamentally complies with Greenwood and Jovanovic's (1990) theory, following the period before reaching the inflection point in the inverted $\mathrm{U}$-shaped relationship.

In fact, the financial system, particularly the banking system, has mainly focused the development on urban areas and served a large audience possessing a great amount of assets, while SMEs or poor households, whose problem is lack of collaterals, have had almost no opportunity to access capital for economic development despite good business ideas or exciting investment projects. To this extent it can be suggested that the financial market has yet to develop to the point where barriers are removed of borrowing costs to the majority of economic actors as pointed out in prior theories, so only a small number of those with higher capital access chances in the financial market may have greatly benefited. In addition, unequal access to financing partly results from the institutional underdevelopment reflected by the financial market. Many banking institutions attempted to operate 'underground,' primarily serving various interest groups. Hence, the financial development in the current period is believed to cause a widening income gap between groups with and without financial accessibility.

\section{Conclusion and recommendations}

\subsection{Conclusion}

In this study we employ data at the provincial level over the period of 2002-2012 to investigate the direction of financial development impact on income inequality in Vietnam. The findings provide evidence to show that the financial development increases the inequality. Unequal chance of accessing finance owing to institutional underdevelopment in which lower economic position is biased in the direction of greater unfavorability is at the core of the problem.

Nevertheless, due to the data constraints, two of many proxies for financial development have been used; thus, a few of its dimensions have yet to be clearly reflected. Furthermore, the studied period lasts approximately ten years, when most provinces were at the early stage of development, and this has not allowed the research to find out a point after which the financial development helps narrow the income gap, thereby leaving space for further investigation. 


\subsection{Recommendations and policy implications}

Based on the research outcomes, we propose some of the recommendations and policy implications as follows:

First, it is nessessary to devise strategies and orient the development of financial markets and banking institutions toward equal chances in financial access for economically disadvantaged groups, such as small enterprises, inhabitants in areas with adverse socio-economic conditions, and low-income communities. This enhances the prospects of economic development and promotes improvements in income and/or living standards for a large proportion of actors currently occupying rural areas in Vietnam.

Second, the state sector, even with a small number of firms, currently sees its credit occupying a large proportion of total domestic credit despite their poor performance, which is another cause of inequality. If such an amount of credit is to be distributed to the non-state sector with better investment efficiency, the economic growth in addition to income distribution should then be improved.

Third, formulating legal institutions accompanying provisions, rules, and regulations in finance-banking activities in accordance with international norms besides other sanctions with powerful deterrent is to control potentially increasing monopoly practices, manipulation, and criminal offenses. Thence, the financial system would function properly to implement the mobilization and allocation of resources to highly efficient activities, hindering the interest groups and thereby creating more equal opportunities for economic actors in financial access.

Fourth, incentive schemes should be offered to facilitate microfinance institutions in expanding their scale and scope of operations. In fact, these institutions serve to create financial access opportunities for the poor and play a major role in poverty alleviation.

Above all, a radical solution is to design a national strategy on financial inclusion with the basic aim to promote and popularize financial or credit services for all classes, in order to provide equal chances for economic development and living stardard improvements, especially for low income groups. Several countries that have achieved considerable success in implementing various target programs on financial inclusion include Brazil, Mexico, China, and the Philippines, from which Vietnam can learn to develop its appropriate strategies 


\section{References}

Ang, J. B. (2010). Finance and inequality: The case of India. Southern Economic Journal, 77, 738761.

Arellano, M., \& Bond, S. (1991). Some tests of specification for panel data: Monte Carlo evidence and an application to employment equations. Review of Economic Studies, 58, 277-297.

Banerjee, A., \& Newman, A. F. (1993). Occupational choice and the process of development. Journal of Political Economy, 101(2), 274-298.

Batuo, M. E., Guidi, F., \& Mlambo, K. (2010). Financial development and income inequality: Evidence from African countries. Retrieved from http://www.afdb.org/fileadmin/uploads/afdb/ Documents/Knowledge/Session\%20II.2.3_1.\%20Financial\%20Development\%20and\%20Incom e\%20Inequality.pdf

Canavire-Bacarreza, G., \& Rioja, F. (2008). Financial development and the distribution of income in Latin America and the Caribbean (IZA Discussion Paper No. 3796). Retrieved from http://ftp.iza.org/dp3796.pdf

Chu, M. H., \& Dong, B. N. (2015). Impact of trade growth on income inequality: Theories and practice (in Vietnamese). Economic Studies Review, 2, 24-33.

Cornia, G. A., \& Court, J. (2001). Inequality, growth, and poverty in the era of liberalization and globalization. Unu-wider, No.4. Helsinki: United Nations University.

Galor, O., \& Zeira, J. (1993). Income distribution and macroeconomics. Review of Economic Studies, $60,35-52$.

Greenwood, J., \& Jovanovic, B. (1990). Financial development, growth, and the distribution of income. Journal of Political Economy, 98, 1076-1107.

Houghton, J., \& Khandker, S. R. (2009). Handbook on poverty and inequality. Washington, DC: The World Bank.

Jauch, S., \& Watzka, S. (2012). Financial development and income inequality: A panel data approach. Retrieved from http://fsaraceno.free.fr/INEQ/jauch_watzka.pdf

La Porta, L.-D.-S., Shleifer, A., \& Vishny, R. (1997). Legal determinants of external finance. Journal of Finance, 52(3), 1131-1150.

Law, S. H., \& Tan, H. B. (2009). The role of financial development on income inequality in Malaysia. Journal of Economic Development, 34(2), 153-168.

Le, Q. H. (2010). Relation between economic growth and income inequality: Theories and practice in Vietnam (in Vietnamese). Economic Studies Review, 1, 14-21. 
Le, Q. H., \& Chu, M. H. (2013). Financial sector development and income inequality in Vietnam: Evidence at the provincial level. Journal of Southeast Asian Economies, 30(3), 263-277.

Liang, Z. (2006a). Financial development and income inequality in rural China 1991-2000. Retrieved from http://www.wider.unu.edu/publications/working-papers/researchpapers/2006/en_GB/rp2006-96/_files/78091789485999999/default/rp2006-96.pdf

Liang, Z. (2006b). Financial development and income distribution: A system GMM panel analysis with application to urban China. Journal of Economic Development, 31(2), 1-21.

Newmand, C., \& O'Tool, C. (2012). Investment financing and financial development: Firm level evidence from Vietnam (Discussion Paper No. 409). Dublin, Ireland: Institute for International Integration Studies.

Nguyen, P. L., \& Anwar, S. (2009). Financial development and economic growth in Vietnam. Journal of Economics and Finance, 35(3), 348-360.

Nguyen, T. V., \& Pham, H. V. (2012). Income inequality in Vietnam: Realities and solutions (in Vietnamese). Journal of Economics \& Development, Special Issue September 2012, 102-110.

OECD. (2011). Society at a glance 2011: OECD social indicator. Retrieved from www.oecd.org/social/societyataglance2011.htm

Ohno, K. (2010). Avoiding the middle income trap: Renovating industrial policy formulation in Vietnam. Hanoi, Vietnam: Vietnam Development Forum (VDF).

Roodman, D. (2006). How to do xtabond2: An introduction to "difference" and "system" GMM in Stata (Working Paper No. 103). Washington, DC: Center for Global Development.

Soto, M. (2009). System GMM estimation with a small sample (Working Paper No. 395). Barcelona, Spain: Barcelona Graduate School of Economics.

The World Bank. (2014a). Taking stock: An update on Vietnam's recent economic development. Retrieved from https://openknowledge.worldbank.org/bitstream/handle/10986/21110/ 928250WP0P13240g0Stock0Dec020140ENG.pdf?sequence $=1$

The World Bank. (2014b). Financial sector assessment Vietnam. Washington, DC: The World Bank.

The World Bank. (2014c). Global financial development report 2014: Financial inclusion. Retrieved from https://openknowledge.worldbank.org/bitstream/handle/10986/16238/9780821399859.pdf? sequence $=4$

Tran, A. T. (2008). Financial sector development and economic growth in the case of Vietnam. Journal of International Business and Economics, 8(2), 135-153.

World Economic Forum. (2011). Inside report: The financial development report 2011. Retrieved from http://www3.weforum.org/docs/WEF_FinancialDevelopmentReport_2011.pdf 